\title{
Phytoplankton dynamics in a coastal jet frontal region*
}

\author{
Maurice Levasseur ${ }^{1}$, Louis Fortier ${ }^{2}$, Jean-Claude Therriault ${ }^{1}$, Paul J. Harrison ${ }^{3}$ \\ ${ }^{1}$ Institut Maurice-Lamontagne, Division d'océanographie biologique, Ministère des Pêches et des Oceans, CP 1000, Mont-Joli, \\ Québec, Canada G5H 3 Z4 \\ ${ }^{2}$ Département de biologie, Université Laval, Ste-Foy, Québec, Canada G1K 7P4 \\ ${ }^{3}$ Department of Oceanography, University of British Columbia, Vancouver, British Columbia, Canada V6T 124
}

\begin{abstract}
We studied the physiological status and turbulent transport of phytoplankton across the quasi-permanent $150 \mathrm{~km}$ long estuarine front separating the Gaspé current from the Anticosti gyre (NW Gulf of St. Lawrence, Canada). In early June, chl a concentrations reached $35 \mu \mathrm{g} \mathrm{l}^{-1}$ in the current, but remained $<1 \mu \mathrm{g} \mathrm{l}^{-1}$ in the gyre. At that time of maximum river runoff and horizontal shear stress, the phytoplankton biomass developing in the current was rapidly transported across the front by turbulent mixing. The strong correlation between chl a and salinity $(\mathrm{r}=-0.96)$ indicated that the rate of crossfrontal dilution far exceeded the rate of phytoplankton production. The $\mathrm{N}: \mathrm{C}$ and $\mathrm{C}: \mathrm{chl}$ a ratios increased and decreased, respectively, with cross-frontal mixing as nutrient-deficient cells from the Gaspé current experienced higher nutrient concentrations and a deepening of the mixed layer in the front. As freshwater runoff and frontal mixing decreased in summer, phytoplankton biomass accumulated in the density front and at the base of the jet current, where low advection and sufficient light and nutrient conditions prevailed. Sporadic upwelling along the front contributed an estimated 5 and $9 \%$ of the total seaward flux of nitrate and silicate, respectively. Thus, nutrients from the drainage basin of the St. Lawrence, rather than the frontal upwelling of deep water, would be responsible for the bulk of the inorganic nutrient flux from the NW Gulf of St. Lawrence to the southern Gulf and the Scotian Shelf.
\end{abstract}

\section{INTRODUCTION}

In the ocean, intense primary production is usually coupled to some hydrodynamic feature that favors the replenishment of nutrients in the photic layer. For example, phytoplankton biomass often develops and accumulates in density fronts where nutrient enrichment of the surface layer may result either from tidal mixing (tidal fronts) or from the interaction between wind stress and internal tides (shelf-break fronts) (see reviews by Holligan 1981, Loder \& Platt 1984, Le Fèvre 1986, Legendre et al. 1986). The breaking of large eddies can also inject nutrients from the mixed to the stratified side of these fronts (Bowman \& Iverson 1978, Loder \& Platt 1984, Le Fèvre 1986).

\footnotetext{
- Contribution to the research programs of the Maurice Lamontagne Institute (Biological Oceanography Division, Department of Fisheries and Oceans, Canada) and of GIROQ (Groupe interuniversitaire de recherches océanographiques du Québec)
}

On the continental shelf, freshwater input from large rivers results in the formation of estuarine plume fronts where nutrient regimes and phytoplankton communities are often distinct from that of the adjacent water masses (Bowman \& Iverson 1978, Tyler \& Seliger 1978, 1981, Seliger et al. 1981, Denman \& Powell 1984, Kahru et al. 1986, Krause et al. 1986). Because estuarine plume fronts are associated with strong buoyancy-driven currents, important shear stress occurs at their boundaries. The resulting cross-frontal circulation is often complex, with considerable horizontal and vertical mixing and the formation of convergence or divergence zones (Tang 1980a, b, Kahru et al. 1986). Thus, contrary to tidal or shelf-break fronts where a given type of turbulent mixing predominates, several different physical forcing functions can be expected to act together or separately in controlling nutrient enrichment and phytoplankton distribution in estuarine plume fronts.

In the Gulf of St. Lawrence, the buoyancy-driven seaward transport of the diluted waters of the St. Law- 
rence estuary forms the Gaspé current, a strong estuarine jet that flows along the Gaspé Peninsula (see Fig. 1). A $150 \mathrm{~km}$ long front develops during spring and summer at the offshore edge of the jet where the strong gradient in current velocity triggers a complex crossfrontal circulation in which both vertical and horizontal mixing and upwelling play major roles (Tang 1980b, 1982, 1983, Benot et al. 1985). The front itself separates 2 semi-enclosed pelagic ecosystems (Sévigny et al. 1979): 'the Gaspé current characterized by continuous high summer production, large-celled diatoms, small copepods, and fish larvae; and the Anticosti gyre, characterized by nutrient-limited phytoplankton growth, small flagellates, large copepod species, euphausids, and decapod larvae'. In summer, nutrient concentrations and phytoplankton biomass tend to be maximum in the front itself (Levasseur et al. 1990).

In this study, we compared the effect of cross-frontal circulation on the small-scale distribution of nutrient and phytoplankton in the Gaspé current frontal region during periods of high (spring) and low (summer) river runoff. In particular, we examined the short-term physiological adjustment of the microalgae to the rapid changes in light and nutrient availability experienced during cross-frontal mixing. In addition, sampling during an upwelling event allowed a punctual assessment of the contribution of frontal upwelling to the total seaward nutrient flux.

\section{MATERIALS AND METHODS}

Three surveys were conducted off Mont-Louis in the Gulf of St. Lawrence (Fig. 1a). The first survey took place at the end of June 1985 during an upwelling event. The other 2 were conducted in 1986: one in early June during the freshet and the other at the end of July during the period of minimum freshwater runoff.

To determine the small-scale cross-frontal distribution of phytoplankton and related variables, water was pumped continuously from a depth of $3 \mathrm{~m}$ along crossfrontal transects (Fig. 1b). Samples were collected every $15 \mathrm{~min}$ from the pump outflow. With the ship steaming at $6 \mathrm{~km} \mathrm{~h}^{-1}$, this sampling frequency corresponded to an average distance of $1.5 \mathrm{~km}$ between samples. Salinity and temperature at the pump outflow were continuously recorded (Inter Ocean, Temp-Sal Model 541).

Within $3 \mathrm{~d}$ after the completion of the horizontal transects, vertical profiles of temperature and salinity (Guildline CTD), nutrients and phytoplankton abundance were conducted at selected stations in the different hydrodynamic areas of the frontal region (Fig. 1b). Samples were collected at different depths by raising the intake hose of a submersible pump from $40 \mathrm{~m}$ to the

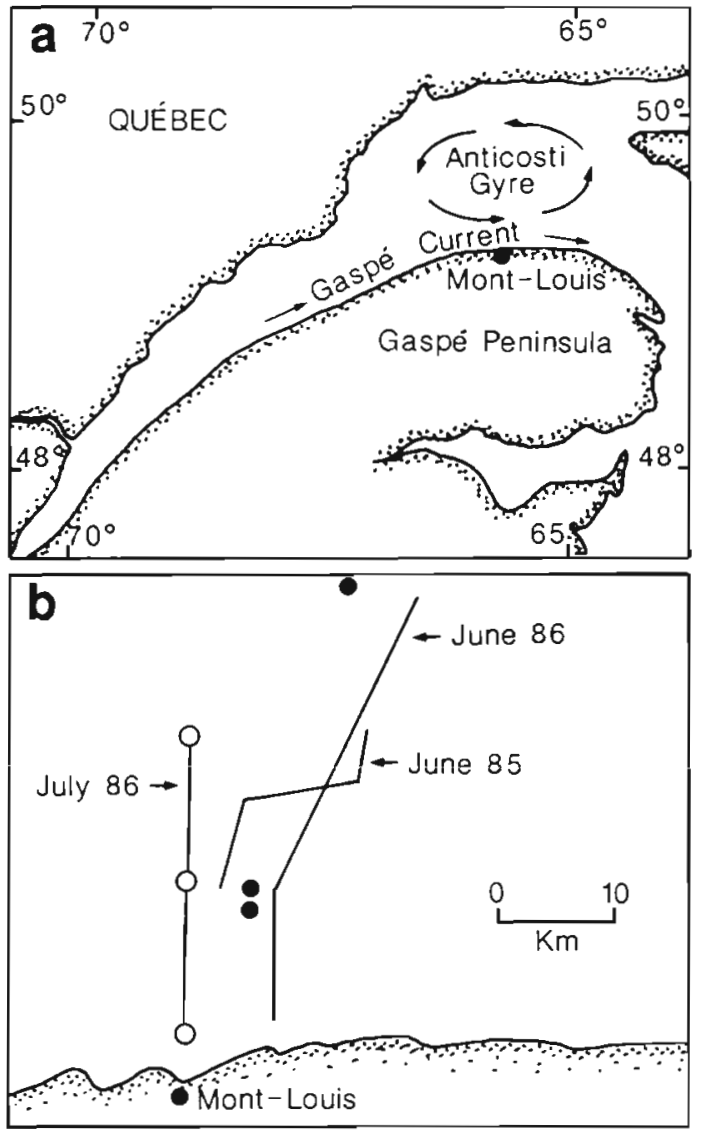

Fig. 1. (a) Northwestern Gulf of St. Lawrence showing the general sampling area and the surface circulation pattern (adapted from El-Sabh 1976). (b) Location of sampling transects (solid lines) off Mont-Louis with position of the stations where vertical sampling was conducted $(\bullet)$ in early June and (O) at the end of July 1986

surface in steps of $2 \mathrm{~m}$, pausing for 2 min at each interval to ensure that the water collected originated from the target depth (early June 1986) or by using a rosette sampler equipped with 2.51 Niskin bottles (end of July 1986). A vertical profile was completed in ca 50 min. In early June 1986, high-resolution cross-section profiles of temperature and salinity were obtained using a vertically oscillating CTD probe (Endeco V-FIN system, Model 1074) towed between 1 and $80 \mathrm{~m}$ along the horizontal transect.

From each water sample, a $250 \mathrm{ml}$ subsample was filtered on a Whatman GF/F filter for chl a determination following the fluorometric method of Yentsch \& Menzel (1963), as modified by Holm-Hansen et al. (1965) (after $24 \mathrm{~h}$ extraction in $90 \%$ acetone). A $500 \mathrm{ml}$ subsample was filtered onto a combusted Whatman $\mathrm{GF} / \mathrm{F}$ filter which was stored frozen in a desiccator for later determination of particulate organic carbon and nitrogen (POC and PON) using a Perkin Elmer ${ }^{(8)}$ ele- 
mental analyser (Sharp 1974). The filtrate was immediately frozen for later determination of nutrients $\left(\mathrm{NO}_{3}{ }^{-}\right.$, $\mathrm{NO}_{2}{ }^{-}$and $\left.\mathrm{SiO}_{4}\right)$, using a Technicon AutoAnalyser ${ }^{(\beta)}$ (Parsons et al. 1984). Finally, a $30 \mathrm{ml}$ subsample was fixed with $1 \mathrm{ml}$ acidic Lugol for phytoplankton enumeration using the inverse microscope technique (Lund et al. 1958).

The elemental composition of particulate matter (Dortch et al. 1985, Sakshaug \& Olsen 1986) was used as an index of the nutritional status of the phytoplankton community. Following the method of Sakshaug et al. (1983), the relative contribution of heterotrophic organisms and detritus to $\mathrm{POC}$ and $\mathrm{PON}$ was estimated by plotting POC (and PON) against chl a. When a significant regression was found, the $y$-intercept was taken as a measure of the POC (or PON) attributable to heterotrophs and detritus and was subtracted from total POC (or PON) in the calculation of phytoplankton N:C and $\mathrm{C}$ : chl a ratios. To account for differences in elemental composition due to differences in species assemblage, an independent regression analysis was conducted in each part of the frontal region. The correction was not applied when the regression was not significant (gyre side of the front in June 1985 and 1986 and entire frontal region in July 1986).

\section{RESULTS}

\section{Hydrography of the frontal region}

The high resolution CTD cross-section conducted in early June 1986 illustrated the typical structure of the frontal region (Fig. 2). The Gaspé current formed a wedge-shaped $15 \mathrm{~m}$ deep layer of relatively warm $(6$ to $8{ }^{\circ} \mathrm{C}$ ) and low salinity (24 to $26 \%$ ) water that extended from the south shore to ca $10 \mathrm{~km}$ offshore. In the Anticosti gyre, offshore, surface waters presented a typical salinity of $30 \%$ with temperatures exceeding $7^{\circ} \mathrm{C}$. The upper mixed layer in the gyre was delimited by a strong thermo-halocline between 20 and $40 \mathrm{~m}$. The transition between the Gaspé current and the Anticosti gyre was marked by strong salinity $(5 \%)$ and temperature $\left(3^{\circ} \mathrm{C}\right)$ gradients. The front, defined as the area where surface salinity varied from 26 to $29 \%$, extended from 10 to $18 \mathrm{~km}$ offshore. Interleaving of the near surface temperature field between 6 and $10 \mathrm{~km}$ offshore suggested that intense mixing took place at the offshore boundary of the current and in the front.

\section{Spring bloom in the Gaspé current (early June 1986)}

The transect path in early June 1986 (Fig. 1b) started in the gyre (salinity at $3 \mathrm{~m}>29 \%$ ), crossed the front

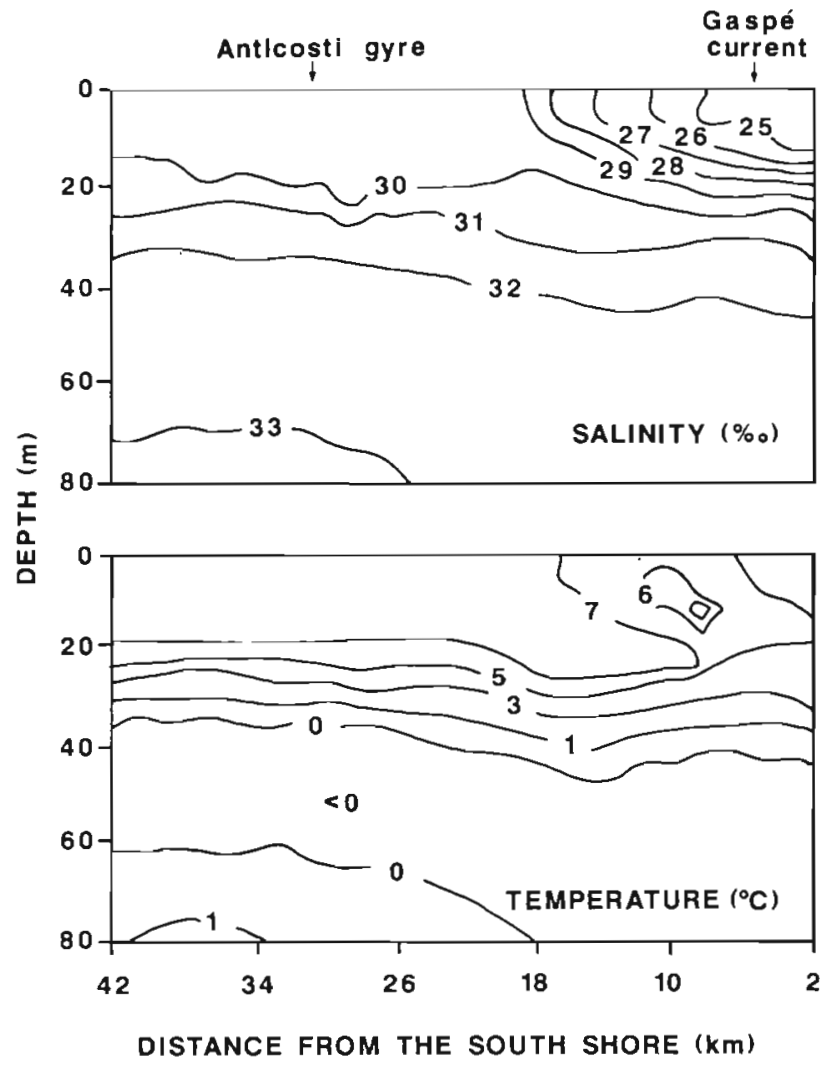

Fig. 2. Cross-frontal sections of salinity and temperature in early June 1986. Data were obtained by towing a vertically oscillating CTD probe (V-FIN ${ }^{(1)}$ system). Duration of transect was $6 \mathrm{~h}$

itself (26 to $29 \%$ ) and entered the Gaspé current $\left(<26 \%\right.$ ) (Fig. 3a). High values of chl a (8 to $35 \mu \mathrm{g} \mathrm{l}^{-1}$ ) were associated with the low salinity surface waters of the Gaspé current (Figs. 3c \& 4b). The community was dominated by the diatom Thalassiosira nordenskioeldii and numerous unidentified small flagellates (Table 1). In the Anticosti gyre, chl a concentrations in the mixed layer were $<1 \mu \mathrm{g} \mathrm{l}^{-1}$ and the community was dominated by unidentified flagellates, dinoflagellates and cryptophytes. In the front (salinity from 25 to $30 \%$ ), chl a concentrations at $3 \mathrm{~m}$ depth decreased linearly as salinity increased ( $r=-0.96, p<0.01$ ) (Fig. 5a), suggesting that the phytoplankton produced in the Gaspé current was passively mixed and diluted with the surface waters of the Anticosti gyre. The structure of the phytoplankton community was similar in the front and the Gaspé current (Table 1).

Nutrient concentrations varied substantially across the frontal region (Fig. $3 \mathrm{~d}$ ). Surface concentrations of nitrate were $<0.3 \mu \mathrm{M}$ in the Gaspé current, between 0.5 and $2.0 \mu \mathrm{M}$ in the front and decreased again to $<0.2 \mu \mathrm{M}$ in the gyre. A few days after the transect, nitrate depletion extended from the surface to about 
Table 1. Phytoplankton species and abundance $\left(10^{3}\right.$ cells $\left.\mathrm{l}^{-1}\right)$ at stations located in the Gaspe current, in the front and in the Anticosti gyre in June and July 1986

\begin{tabular}{|c|c|c|c|c|c|c|c|}
\hline \multirow[t]{3}{*}{ Species } & \multicolumn{3}{|c|}{ June 1986} & \multicolumn{4}{|c|}{ July 1986} \\
\hline & \multirow{2}{*}{$\begin{array}{c}\text { Gaspé current } \\
3 \mathrm{~m}\end{array}$} & \multirow{2}{*}{$\begin{array}{c}\text { Front } \\
3 \mathrm{~m}\end{array}$} & \multirow{2}{*}{$\begin{array}{l}\text { Gyre } \\
3 \mathrm{~m}\end{array}$} & \multicolumn{2}{|c|}{ Gaspé current } & \multirow{2}{*}{$\begin{array}{c}\text { Front } \\
3 \mathrm{~m}\end{array}$} & \multirow{2}{*}{$\begin{array}{l}\text { Gyre } \\
3 \mathrm{~m}\end{array}$} \\
\hline & & & & $3 \mathrm{~m}$ & $24 \mathrm{~m}$ & & \\
\hline \multicolumn{8}{|l|}{ Bacillariophyceae } \\
\hline Chaetoceros convolutus & - & - & - & 2 & - & 3 & - \\
\hline C. debilis & 24 & - & - & 54 & 306 & - & - \\
\hline C. diadema & 36 & - & - & - & - & - & - \\
\hline C. furcelatus & 12 & - & - & - & 2 & - & - \\
\hline C. laciniosus & 147 & 25 & - & 14 & 21 & 5 & - \\
\hline C. septentrionalis & 37 & - & - & - & - & - & - \\
\hline C. similis & 12 & - & - & - & 6 & - & - \\
\hline Chaetoceros sp. & 306 & 74 & - & & - & - & - \\
\hline Leptocylindrus danicus & - & - & - & 2 & 2 & - & - \\
\hline L. minimus & - & - & - & 3 & 11 & 32 & 5 \\
\hline Nitzschia closterium & - & - & - & - & 7 & 3 & 1 \\
\hline N. delicatissima & 37 & 12 & - & 1 & 4 & 22 & 11 \\
\hline N. longissima & - & 25 & - & - & - & - & - \\
\hline Skeletonema costatum & 49 & - & - & 5 & 3 & 23 & - \\
\hline Thalassionema nitzschioides & - & - & - & - & - & 1 & - \\
\hline Thalassiosira anguste-lineata & - & - & - & 2 & - & - & - \\
\hline T. gravida & 25 & - & - & 10 & 220 & - & - \\
\hline T. nordenskioeldii & 2920 & 613 & - & 18 & 600 & 11 & - \\
\hline T. pacifica & 98 & - & - & - & - & - & - \\
\hline Thalassiosira spp. & - & 74 & - & 16 & - & - & 3 \\
\hline Unidentified pennates & 12 & - & - & 1 & 1 & 2 & - \\
\hline \multicolumn{8}{|l|}{ Dinophyceae } \\
\hline Ceratium longibipes & - & - & - & - & - & - & 1 \\
\hline C. triacantha & - & - & - & - & - & - & 1 \\
\hline Gymnodinium spp. & - & - & 78 & 41 & 20 & 39 & 26 \\
\hline Gyrodinium grenlandicum & - & - & - & 25 & 25 & 3 & - \\
\hline Heterocapsa triquetra & - & - & - & 2 & - & 9 & 7 \\
\hline Katodinium rotundatum & - & - & - & - & - & 12 & - \\
\hline Prorocentrum bipes & - & - & - & - & - & 2 & - \\
\hline P. brevipes & - & - & - & - & - & - & 1 \\
\hline Scrippsiella trochoidea & - & - & - & 2 & - & - & - \\
\hline Unidentified dinoflagellates & 134 & 73 & 73 & - & 1 & 1 & 3 \\
\hline \multicolumn{8}{|l|}{ Chrysophyceae } \\
\hline Apedinella spinifera & 49 & - & - & 12 & - & 25 & 25 \\
\hline Dinobryon balticum & - & 12 & - & 4 & 12 & - & - \\
\hline D. petiolatum & - & - & - & - & - & 12 & - \\
\hline \multicolumn{8}{|l|}{ Cryptophyceae } \\
\hline Leucocryptos marina & - & - & - & 12 & 74 & 37 & 61 \\
\hline Unidentified & 147 & 74 & 147 & - & - & - & - \\
\hline \multicolumn{8}{|l|}{ Prasinophyceae } \\
\hline Unidentified & 37 & 49 & 37 & 159 & 12 & 74 & - \\
\hline \multicolumn{8}{|l|}{ Others } \\
\hline Unidentified flagellates & 956 & 1300 & 380 & 220 & 282 & 330 & 184 \\
\hline Others & 1050 & 625 & 270 & - & - & - & - \\
\hline
\end{tabular}

$20 \mathrm{~m}$ in all 3 hydrographic areas (Fig. 4c). The crossfrontal pattern of silicate concentration was similar to that of nitrate, with maximum values in the front (ca $3.5 \mu \mathrm{M}$ ) and lower values in the Gaspé current and the gyre (ca $2 \mu \mathrm{M}$ ). The low nutrient concentrations measured in the Gaspé current suggested that the spring diatom bloom had reached a relatively advanced stage. Within the Gaspé current and the front, nutrient concentrations were positively correlated with the depth of the mixed layer (Table 2)

In early June, variations in the physiological status of the community paralleled cross-frontal variations in 

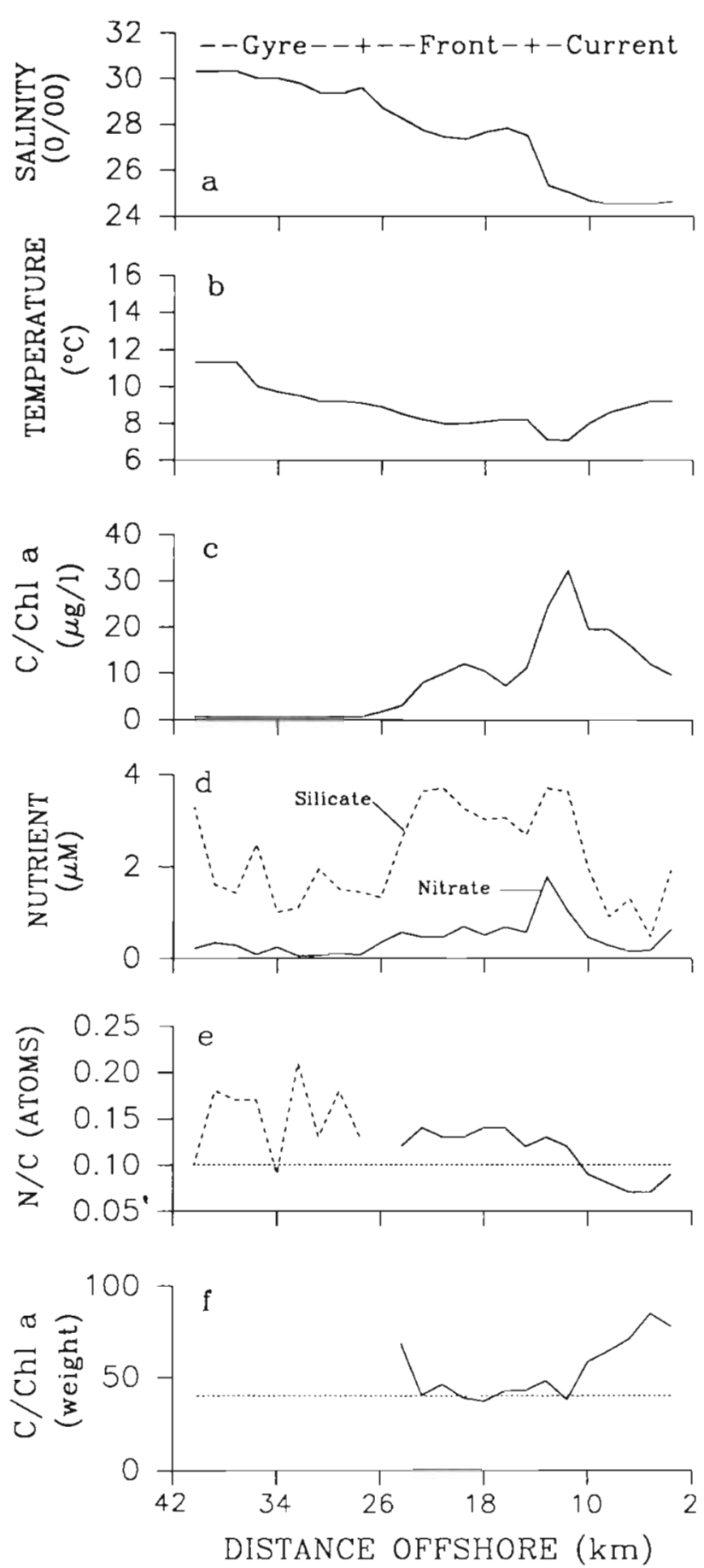

Fig. 3. Horizontal distribution at $3 \mathrm{~m}$ of the variables measured in early June 1986: (a) salinity; (b) temperature; (c) chl $a_{\text {; }}$ (d) $\mathrm{NO}_{3}{ }^{-}$and $\mathrm{SiO}_{4}$; (e) $\mathrm{N}$ : C ratio of phytoplankton (solid line) or seston (dashed line) and value of the Redfield ratio (dotted line) (Redfield et al. 1963); and (f) C: chl a ratio of phytoplankton (solid line) and mean value of the ratio for healthy phytoplankton cells (dotted line) (Harrison et al. 1977)

nutrient concentration and mixed layer depth. The phytoplankton $\mathrm{N}$ : C ratio was generally $<0.10$ in the nutrient-impoverished Gaspé current, indicating potential nutrient deficiency (Fig. 3e), and increased gradually to ca 0.14 in the front (a value generally indicative of nutrient sufficiency). The $\mathrm{C}$ : chl a ratio, an index of the light regime recently experienced by the cells, was $>40$ in the Gaspé current and ca 40 in the front itself (Fig. 3f). These values suggested that the phytoplankton was adapted to lower light intensity in the front where the depth of the mixed layer was greater. Variations in both ratios were linearly and significantly correlated to silicate concentration and the depth of the mixed layer, but not to nitrate concentration (Fig. 6, Table 2).

\section{Summer production in the front (late July 1986)}

The cross-frontal distribution of salinity in late July was similar to that observed in early June, except that the gradient was weaker (Fig. 7a). In contrast with the spring bloom period when chl a concentrations reached $35 \mathrm{\mu g} \mathrm{l}^{-1}$ in the current, near-surface $(3 \mathrm{~m})$ phytoplankton biomass was low $\left(<0.4 \mu \mathrm{g} \mathrm{I}^{-1}\right)$ and varied little across the frontal region (Fig. $7 \mathrm{c}$ ). There was no significant relationship between chl a and salinity (Fig. 5b). Vertical profiles at selected stations confirmed that biomass was low from the surface to $15 \mathrm{~m}$ in all areas of the frontal region (Fig. 8b). Phytoplankton biomass was concentrated in a subsurface chl a maximum located between 25 and $30 \mathrm{~m}$ in the Gaspé current and between 20 and $25 \mathrm{~m}$ in the frontal area. No subsurface chl a maximum was observed in the gyre where biomass was uniformly low (Fig. 8b).

In the mixed layer, the phytoplankton community was numerically dominated by small unidentified flagellates at all stations ( $3 \mathrm{~m}$; Table 1$)$. The cryptophyte Leucocryptos marina, the dinoflagellate Gymnodinium spp. and the chrysophyte Apedinella spinifera were important in the gyre, whereas substantial numbers of unidentified prasinophytes were found in the surface layer of the Gaspé current and the front.

Table 2. Simple Pearson's coefficients of linear correlation between phytoplankton biochemical composition, mixed layer depth (MLD) and nutrient concentrations at $3 \mathrm{~m}$ depth along the transect crossing the Gaspé current and the front in the spring bloom period (early June 1986) $\mathrm{n}=14$

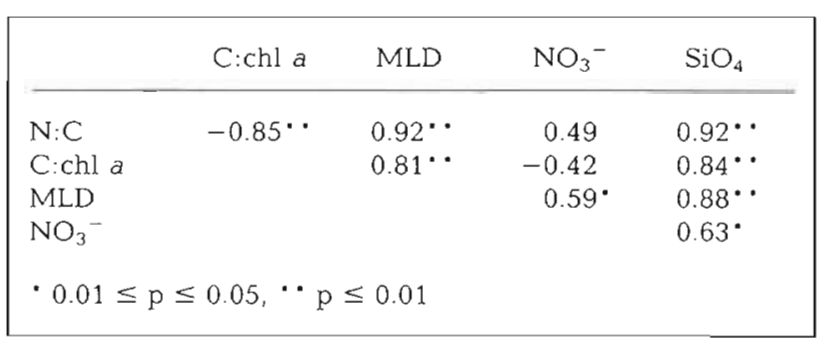



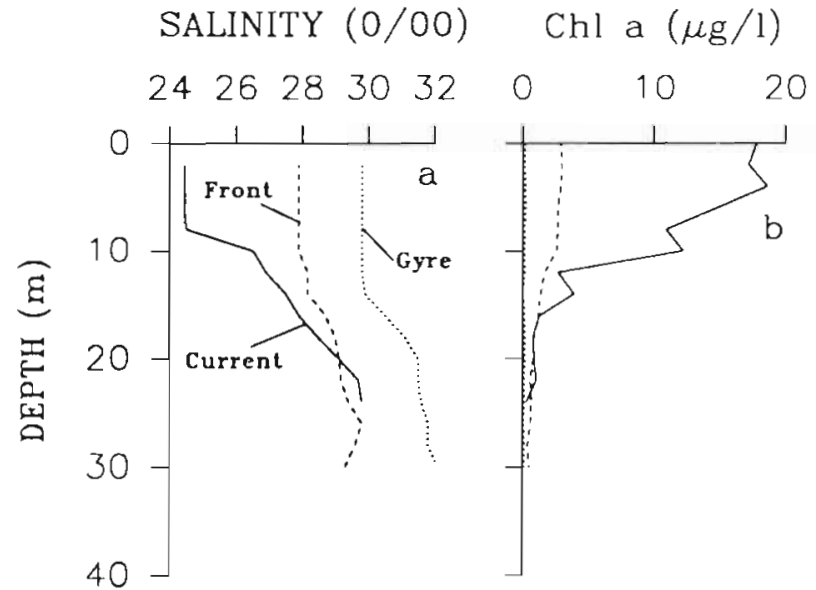

Chaetoceros debilis and Thalassiosira nordenskioeldii (the same diatoms that dominated the late spring bloom in the Gaspé current in early June) prevailed in the deep chl a maximum (Table 1).

Maximum near-surface concentrations of nitrate $(1.8 \mu \mathrm{M})$ and silicate $(4.0 \mu \mathrm{M})$ were found in the front (Fig. 7 d). Elsewhere in the frontal region, $\mathrm{NO}_{3}{ }^{-}$and $\mathrm{SiO}_{4}$ concentrations in the surface mixed layer were generally $<0.5$ and $1.8 \mu \mathrm{M}$, respectively (Figs. $7 \mathrm{~d} \& 8 \mathrm{c}$ ). Below $15 \mathrm{~m}$, concentrations of $\mathrm{NO}_{3}{ }^{-}$(Fig. 8c) and $\mathrm{SiO}_{4}$ (not shown) increased sharply to reach a maximum between 20 and $30 \mathrm{~m}$ at all stations. The $\mathrm{N}$ : C ratio of the seston was ca 0.15 in the Gaspé current and in the front and decreased to 0.10 at 2 stations in the gyre (Fig. 7e). Variations in the $\mathrm{C}: \mathrm{chl}$ a ratio (for seston) presented no obvious pattern and appeared unrelated to the hydrography of the frontal region (Fig. $7 \mathrm{f}$ ).

\section{Frontal upwelling (late June 1985)}

In late June 1985, the trajectory of the sampling transect was designed to maximize the number of samples collected in the front (Fig. 1b). The dominant hydrographic feature along the cross-frontal transect at that time was the upwelling of high salinity (29.5\%) and low temperature $\left(9\right.$ to $\left.10^{\circ} \mathrm{C}\right)$ water in the front, at the offshore edge of the current (Fig. $9 a, b$ ). Nitrate and silicate concentrations were 5 times higher in the upwelled water $\left(\mathrm{NO}_{3}{ }^{-}=3\right.$ to $6 \mu \mathrm{M} ; \mathrm{SiO}_{4}=3$ to $\left.5 \mu \mathrm{M}\right)$ than in surrounding waters $(<1.5 \mu \mathrm{M})$. Extremely high concentrations of chl a (up to $55 \mu \mathrm{g} \mathrm{l}^{-1}$ ) were measured in the near-surface waters of the upwelling (Fig. 9c), associated with the intermediate salinities of the front (Fig. 5c). Peaks of biomass were also observed downstream of the upwelling, on the gyre side of the front (Fig. 9c). These peaks were associated with relatively cool waters, but low nutrient concentrations. The diatom Thalassiosira nordenskioeldiu dominated the

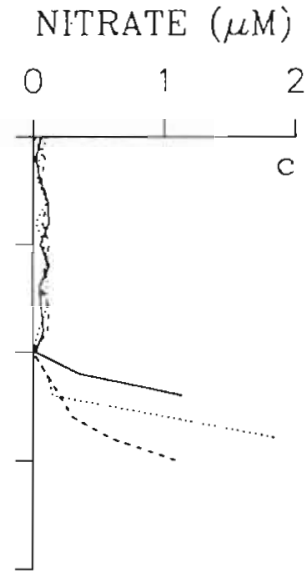

Fig. 4. Vertical distribution of (a) salinity, (b) chl a concentrations and (c) $\mathrm{NO}_{3}{ }^{-}$in the Gaspe current, the front and the Anticosti gyre in early June 1986 phytoplankton community in the upwelled water and the downstream peaks of biomass (Table 3). In the surrounding waters, chl a concentrations varied between 0.5 and $5 \mu \mathrm{g} \mathrm{l}^{-1}$ and the phytoplankton community was dominated by small flagellates and the diatom Chaetoceros sp.

The phytoplankton $\mathrm{N}: \mathrm{C}$ ratio was $>0.10$ in the upwelling and the surrounding waters, and started to decline at the offshore limit of the front, near the gyre where low concentrations of $\mathrm{NO}_{3}{ }^{-}$and $\mathrm{SiO}_{4}$ prevailed (Fig. 9e). The phytoplankton $C$ : chl a ratio was $>100$ in

Table 3. Phytoplankton species composition and abundance $\left(10^{3}\right.$ cells $\left.\mathrm{l}^{-1}\right)$ at $3 \mathrm{~m}$ depth in the upwelling and in surrounding waters in June 1985

\begin{tabular}{|lrc|}
\hline & $\begin{array}{c}\text { Surrounding } \\
\text { water }\end{array}$ & $\begin{array}{c}\text { Upwelled } \\
\text { water }\end{array}$ \\
\hline Bacillariophyceae & & \\
Chaetoceros sp. & 372 & 80 \\
Nitzschia closterium & 27 & - \\
$N$. delicatissima & 9 & - \\
Thalassiosira gravida & - & 36 \\
$T$ nordenskioeldii & 44 & 1190 \\
Thalassiosira sp. & - & 18 \\
Unidentified pennates & - & 27 \\
Unidentified centrales & 27 & - \\
Dinophyceae & & \\
Gymnodinium spp. & 80 & 44 \\
Katodinium rotundatum & 9 & - \\
Chrysophyceae & & \\
Apedinella spinifera & - & 389 \\
Dinobryon balticum & 17 & \\
Cryptophyceae & & 513 \\
Unidentified & 274 & \\
Others & & \\
Unidentified flagellates & 2070 & \\
\hline
\end{tabular}




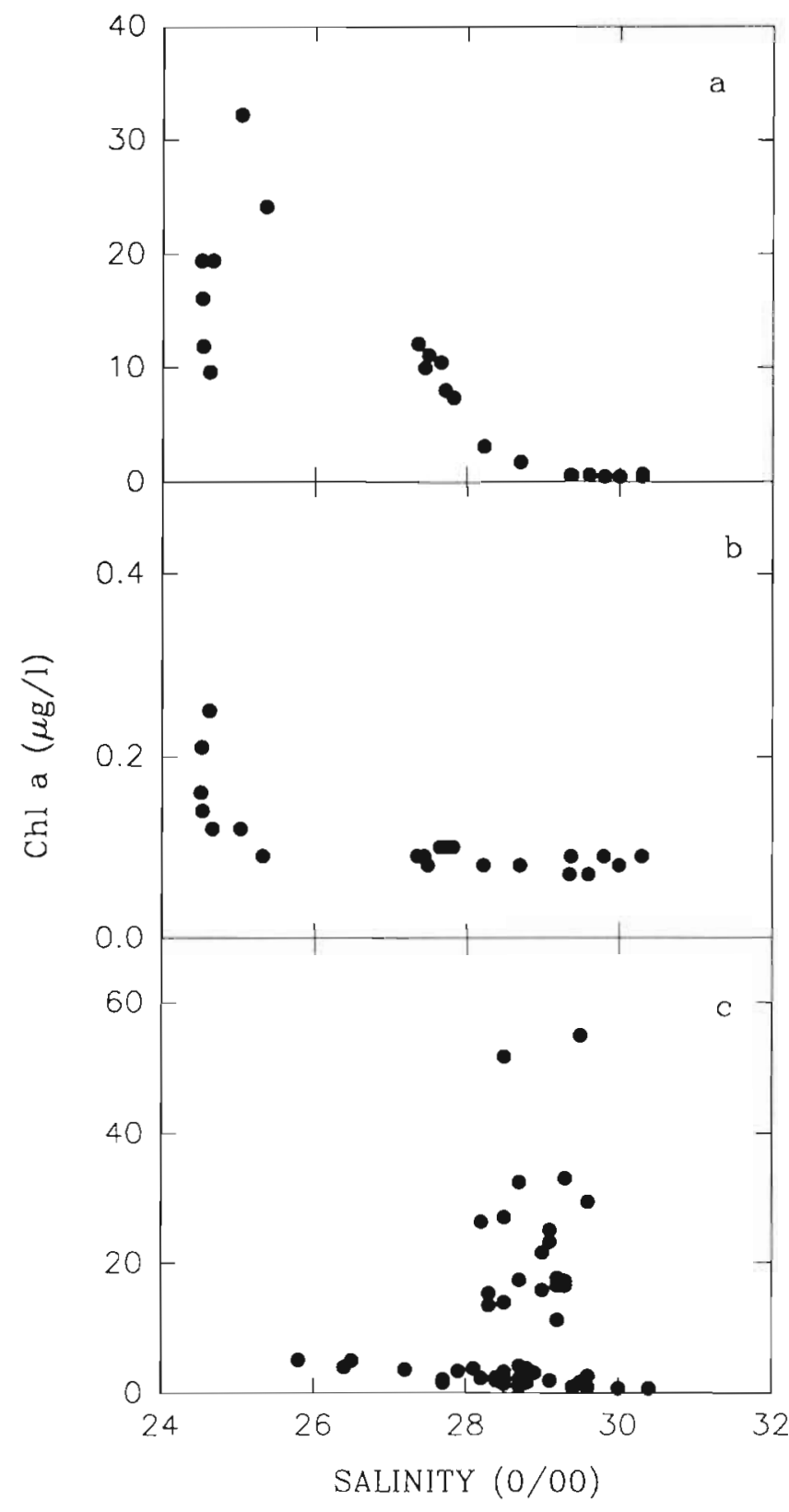

Fig. 5. Chl a concentrations vs salinity measured at $3 \mathrm{~m}$ for (a) early Jume 1986, (b) end of July 1986 and (c) end of June 1985 sampling periods

the Gaspé current. Values $<40$ in and downstream of the upwelling suggested acclimatation of the cells to low light levels (Fig. 9f).

\section{DISCUSSION}

\section{Cross-frontal mixing of the Gaspé current spring bloom}

The estuarine front between the Gaspé current and the Anticosti gyre separates 2 semi-enclosed ecosys- tems (Sévigny et al. 1979). The buoyancy-driven Gaspé current is formed by the seaward advection of the diluted waters of the St. Lawrence, and variations in its properties (e.g. nutrients and phytoplankton biomass) primarily reflect the conditions developing in the lower estuary (Therriault \& Levasseur 1985). For example, the high concentration of chl a observed in early June in the Gaspé current (up to $35 \mu \mathrm{g} \mathrm{l}^{-1}$ ) are comparable to those reported for the lower estuary in early summer (Sévigny et al. 1979, Sinclair et al. 1981, Levasseur et al. 1984). The diatoms Thalassiosira nordenskioeldii and Chaetoceros sp. which dominated the biomass are typical of the assemblage found in this season in the lower estuary (Therriault \& Levasseur 1985). In the Anticosti gyre, the low nutrient concentrations and phytoplankton biomass, as well as a community dominated by small flagellates and dinoflagellates, are typical of the post spring-bloom conditions prevailing over most of the Gulf of St. Lawrence in summer.

Within the front itself, variations in salinity explained $92 \%$ of the variations in phytoplankton biomass during the spring bloom. The linearity of the chl a-salinity relationship suggested that the rate of cross-frontal mixing was high enough to disperse the spatial heterogeneity in biomass that normally develops in a fast-growing phytoplankton community. Both the ambient nutrient levels and the biochemical composition of the cells indicated that growth was not limited in the front and that turbulent mixing must have been intense to smooth out the phytoplankton distribution. We conclude that cross-frontal dilution of the bloom occurred over a time scale much shorter than days, i.e. shorter than the time scale of biomass accumulation in nutrient sufficient phytoplankton assemblages (e.g. Harris 1980). Similar dilutions of phytoplankton biomass across an estuarine plume front have been reported by Bowman \& Iverson (1978) for the Hudson River and by Kahru et al. (1986) for the Baltic Sea.

Previous studies of the circulation in the Gaspé current also suggest intense turbulent mixing across the front in late spring when freshwater runoff of the St. Lawrence is near its annual maximum (El-Sabh 1979). Water velocity in early June reaches $110 \mathrm{~cm} \mathrm{~s}^{-1}$ in the Gaspé current (Benoît et al. 1985). Consistent with our conclusion based on the co-distribution of chl a and salinity, high shear stress and turbulent mixing are expected in the front where a sharp gradient in current speed exists between the fast flowing water of the Gaspé current and the slower cyclonic circulation of the gyre (Benoît et al. 1985).

In spite of rapid cross-frontal mixing, the residence time of the phytoplankton community in the front was long enough (hours; Harris 1980) for some physiological adjustment to the frontal nutrient and light regimes to take place. Frontal mixing resulted in a deepening of 

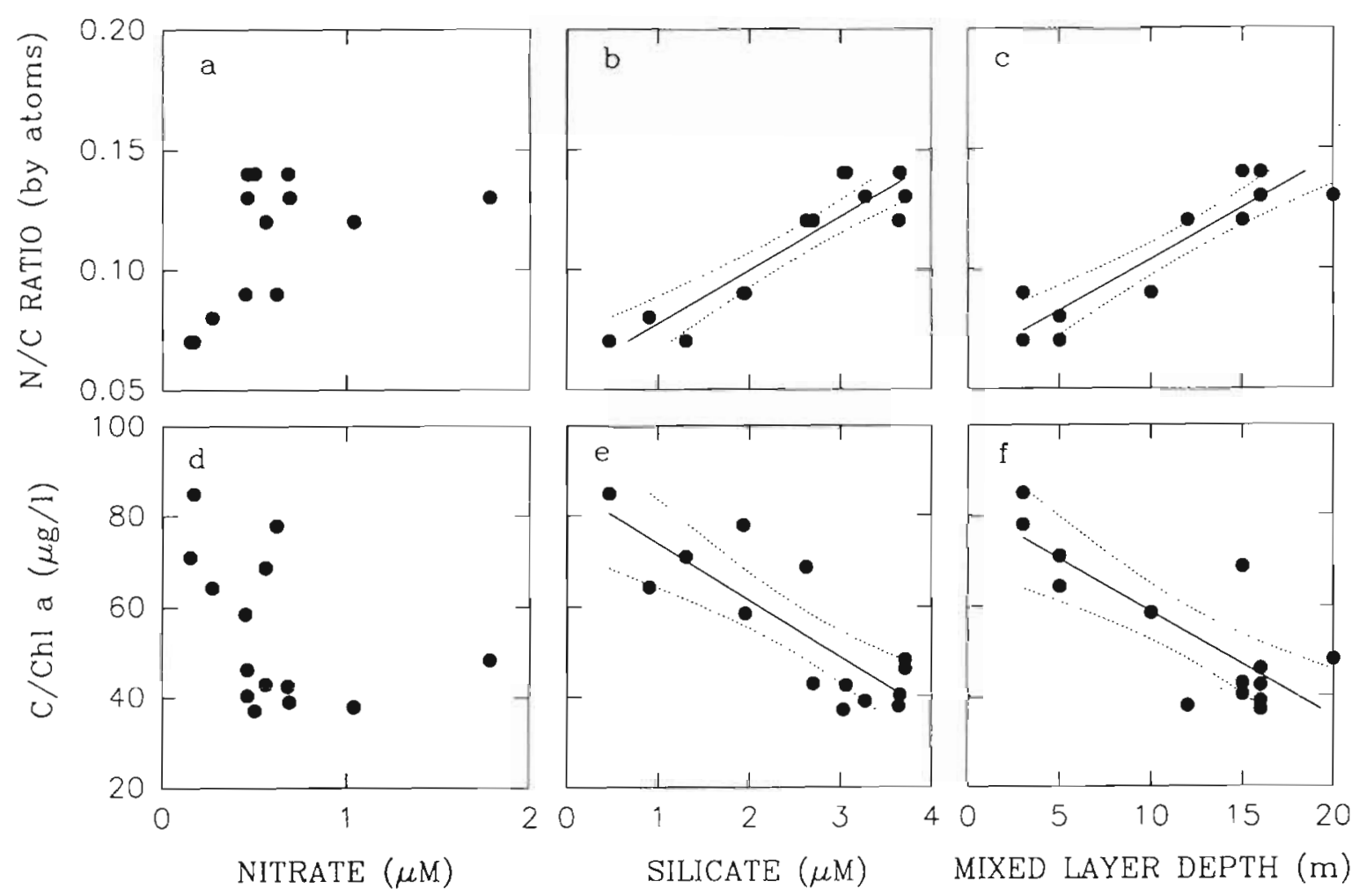

Fig. 6. Phytoplankton $\mathrm{N}: \mathrm{C}$ and $\mathrm{C}: \mathrm{chl}$ a ratios vs (a \& d) $\mathrm{NO}_{3}{ }^{-}$concentrations, and (b \& e) $\mathrm{SiO}_{4}$ concentrations measured at $3 \mathrm{~m}$ depth, and $(\mathrm{c} \& \mathrm{f})$ the mixed layer depth during the transect conducted in early June 1986. Dotted lines represent $95 \%$ confidence interval

the surface mixed layer (from $4 \mathrm{~m}$ in the current to $20 \mathrm{~m}$ in the front) and in an increase in $\mathrm{NO}_{3}{ }^{-}$and $\mathrm{SiO}_{4}$ surface concentrations. As a consequence, variations in nitrate and silicate concentration across the front were positively correlated with the mixed layer depth. As they were mixed across the front, phytoplankton cells experienced increasing nutrient concentrations, and the $\mathrm{N}$ : C ratio of the cell increased. The increase in $\mathrm{N}: \mathrm{C}$ ratio was positively correlated with silicate concentration, but not with nitrate concentration, a situation previously observed in the area (Levasseur et al. 1990). As shown in the laboratory, silicate-deficient cells often exhibit low N:C ratios (Harrison et al. 1977). This suggests that the diatom community was silicate-deficient in the Gaspé current and became progressively silicate-sufficient as it crossed the front. Similarly, the decrease in the $C$ : chl a ratio of the cells paralleled the decrease in irradiance associated with the increase in mixed layer depth experienced during the transit across the front.

\section{Subsurface summer production in the front}

At the end of July, nutrient and chl a concentrations had drastically declined in the Gaspé current and a typical summer community dominated by flagellates and dinoflagellates had replaced the spring diatom bloom. In the Anticosti gyre, nutrient and phytoplankton concentrations remained low.

In contrast to spring conditions, the lack of relationship between near surface salinity and chl a in late July suggested that the summer decrease in freshwater runoff was accompanied by a decrease in the intensity of cross-frontal mixing. Benoît et al. (1985) observed that the maximum speed of the Gaspé current decreases from 110 to $60 \mathrm{~cm} \mathrm{~s}^{-1}$ from June to November. In late July, chl a concentrations were maximum in the front itself and formed a subsurface tongue that extended under the current (Fig. 8b). The phytoplankton community in the front was distinct from that of the adjacent waters, but was similar to the community found in the Gaspé current in spring. Adequate light and nutrient conditions may explain the subsurface growth of the spring diatom community retained at the boundary of the current by the slower advection (Benoit et al. 1985) and by the cross-frontal circulation proposed by Tang (1980b). Secchi disk readings in the Gaspé current indicated that light was sufficient for phytoplankton growth at $20 \mathrm{~m}(>1 \%$ of incident irradiance), a depth which corresponded to the halocline and the subsurface chl a maximum. 

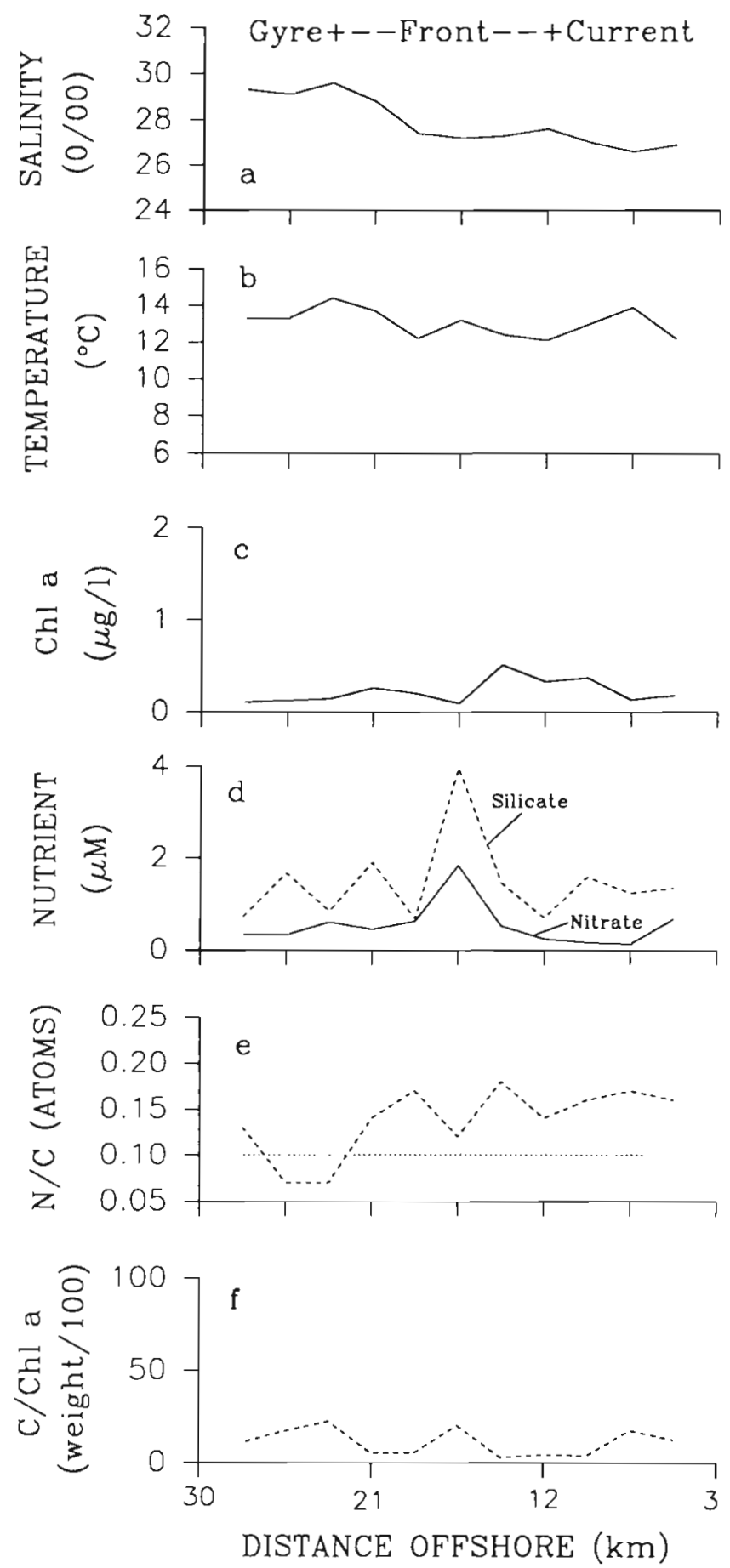

Fig. 7. Horizontal distribution at $3 \mathrm{~m}$ of the variables measured at the end of July 1986: (a) salinity; (b) temperature; (c) chl $a_{\text {; }}$ (d) $\mathrm{NO}_{3}{ }^{-}$and $\mathrm{SiO}_{4}$; (e) N:C ratio of seston and value of the Redfield ratio (dotted line) (Redfield et al. 1963); and (f) C:chl a ratio of seston

The seasonal decrease of the intensity of the crossfrontal mixing between spring and summer is probably typical of temperate riverine and estuarine fronts characterized by a summer decline in freshwater runoff. This seasonal stabilization of cross-frontal mixing may favor the development of distinct phytoplankton communities in the front in summer (Seliger et al. 1981, Krause et al. 1986).

\section{Frontal upwelling, seaward nutrient transport and the productivity of the Gulf of St. Lawrence}

Fronts are often characterized by downwelling and upwelling (Bowman \& Iverson 1978). For example, an uplifting of the near-surface isotherms resulting in a narrow band of cold surface waters has been previously observed on the mixed side of shallow sea fronts (James 1978, Kahru et al. 1986, Krause et al. 1986, Van Heijst 1986). Tang (1982, 1983) has proposed a mechanism for the generation of the upwelling along the Gaspé current front (Fig. 10). In his model, the strong vertical shear across the interface induces an Ekman transport along the interface which is directed away from the front. A convergence zone is created at the edge of the front and, in order to insure mass continuity, a compensating flow of water is drawn directly from below the current.

Newly-upwelled waters are normally rich in nutrients and poor in phytoplankton, and this pattern reverses downstream of the upwelling center as nutrients are consumed and the algal biomass increases (e.g. Wilkerson \& Dugdale 1987). The cooccurrence of high levels of nutrients and phytoplankton suggests that most of the biomass is already present in the waters upwelled along the Gaspé current front (this study, Levasseur et al. 1990). This observation is in agreement with the circulation model of Tang (1980b), which proposes that the upwelled waters are drawn directly from the base of the Gaspé current where, according to our result, phytoplankton biomass accumulates in summer to form a subsurface chlorophyll maximum. The physiological status of the cells in the upwelling also supports the hypothesis that they originated from the base of the Gaspé current where high concentrations of nutrients and low light levels prevailed: a $\mathrm{N}$ : C ratio $>0.10$ suggested that the upwelled community was nutrient-sufficient and a $C$ : chl a ratio $<40$ suggested an adaptation to low light intensity (Richardson et al. 1986). Since adaptation to high light occurs over a time scale of hours (Falkowski 1984), the low C: chl a ratios measured in the upwelling part of the front indicated that the cells had only recently been exposed to higher near-surface irradiance.

The parcels (ca $5 \mathrm{~km}$ in diameter) of relatively cool water observed downstream of the upwelling center on the gyre side of the front contained high densities of the same diatoms found in the newly-upwelled waters and 


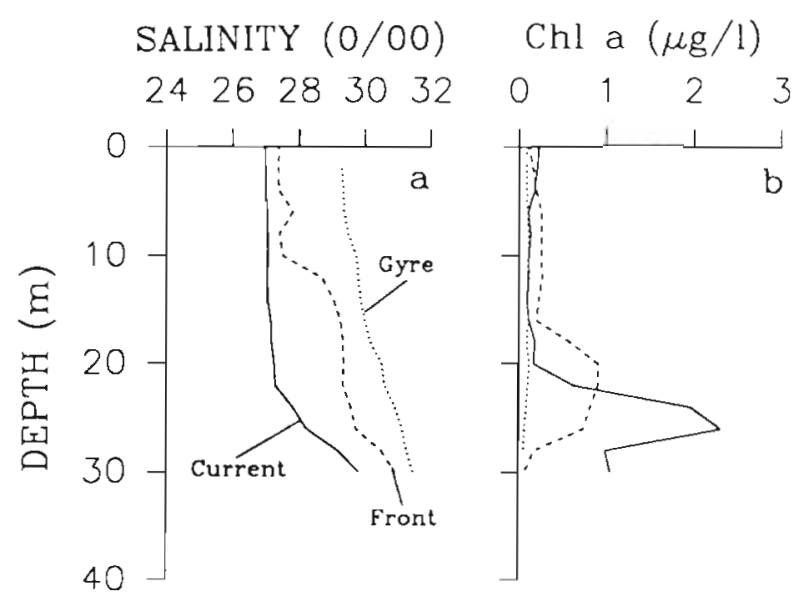

probably represented older upwellings. Low concentrations of nitrate and silicate in these parcels of water indicate that the bulk of the upwelled nutrients were consumed within the front.

Correlations have been detected between the seasonal discharge of the St. Lawrence and landings of crustaceans and finfish in the Gulf of St. Lawrence (Sutcliffe 1972, 1973, Bugden et al. 1982, see also Drinkwater et al. 1991 for a recent review). Among different explanations for the correlations, Bugden et al. (1982) hypothesized that an intensification of frontal upwelling along the Gaspé current front in years of high freshwater discharge would increase the flux of nutrients to the Gulf. The resulting increase in productivity would create favorable conditions for the survival of the larval stages of commercial fish.

The data collected during an upwelling event in late June 1985 allow a rough assessment of the potential contribution of the frontal upwelling to the seaward flux of inorganic nutrient (Table 4). Using Tang's (1982) estimate of upwelling rate $\left(40 \mathrm{~mm} \mathrm{~s}^{-1}\right)$ and the nutrient concentrations at the base of the current $\left(\mathrm{NO}_{3}{ }^{-}=\right.$ $\left.6.0 \mu \mathrm{M} ; \mathrm{SiO}_{4}=4.5 \mu \mathrm{M}\right)$, the calculated vertical flux is $8.6 \mathrm{~mol} \mathrm{~km}^{-2} \mathrm{~h}^{-1}$ for $\mathrm{NO}_{3}^{-}$and $6.4 \mathrm{~mol} \mathrm{~km}{ }^{-2} \mathrm{~h}^{-1}$ for $\mathrm{SiO}_{4}$. Satellite pictures indicate that the upwelling cir-

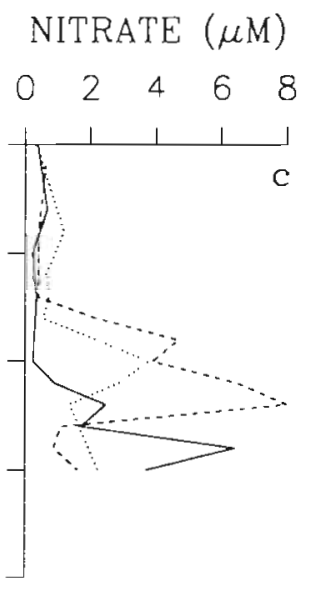

Fig. 8. Vertical distribution of (a) salinity, (b) chl a concentrations and (c) $\mathrm{NO}_{3}{ }^{-}$ in the Gasper current, the front and the Anticosti gyre at the end of July 1986 culation is often present all along the front (Tang 1980b, Benoît et al. 1985, El-Sabh \& Benoît 1985). Assuming an upwelling area of ca $1500 \mathrm{~km}^{2}$ (mean width and length of 10 and $150 \mathrm{~km}$, respectively; i.e. the upwelling is present along the entire length of the front), 13 and $10 \mathrm{kmol} \mathrm{h}^{-1}$ of $\mathrm{NO}_{3}{ }^{-}$and $\mathrm{SiO}_{4}$, respectively, could be brought to the surface. Sinclair et al. (1976) estimated the mean seaward flux of nutrient from the lower estuary in June to be $143 \mathrm{kmol} \mathrm{h}^{-1}$ for $\mathrm{NO}_{3}{ }^{-}$and $214 \mathrm{kmol} \mathrm{h}^{-1}$ for $\mathrm{SiO}_{4}$. Nutrients upwelled along the Gaspé current front would then represent only a small fraction $\left(9 \%\right.$ for $\mathrm{NO}_{3}{ }^{-}$and $5 \%$ for $\left.\mathrm{SiO}_{4}\right)$ of the contribution of the lower estuary to the total seaward nutrient flux. Our estimates should however be considered with caution since they do not take into account spatio-temporal variations in shear stress and upwelling velocity along the front. Satellite pictures indicate that the frontal upwelling may be restricted only to small parts of the front (Tang 1980a). In this case, the contribution of the upwelling circulation to the seaward nutrients fluxes would be decreased significantly. Spatio-temporal variations in nutrient concentrations at the base of the current for in the upwelled waters) may also have an influence on our estimates, but problably only to a small extent, since

Table 4. Estimation of the relative contribution of the upwelling circulation to the seaward flux of $\mathrm{NO}_{3}{ }^{-}$and $\mathrm{SiO}_{4}$ to the Gulf

\begin{tabular}{|c|c|c|c|}
\hline Variables & Units & $\mathrm{NO}_{3}{ }^{-}$ & $\mathrm{SiO}_{4}$ \\
\hline Mean concentrations in the upwelled water & $\mu \mathrm{M}$ & 6.0 & 4.5 \\
\hline Vertical flux ${ }^{a}$ & $\mathrm{~mol} \mathrm{~km} \mathrm{k}^{-2} \mathrm{~h}^{-1}$ & 8.6 & 6.4 \\
\hline Integrated vertical flux ${ }^{b}$ & $\mathrm{kmol} \mathrm{h}^{-1}$ & 13 & 10 \\
\hline Seaward flux from the lower estuaryc & $\mathrm{kmol} \mathrm{h}^{-1}$ & 143 & 214 \\
\hline Relative contribution of the upwelling to the nutrient seaward flux & $\%$ & 9 & 5 \\
\hline \multicolumn{4}{|l|}{${ }^{a}$ Using an upwelling vertical velocity of $40 \mathrm{~mm} \mathrm{~s}^{-1}$ (Tang 1982) } \\
\hline \multicolumn{4}{|l|}{${ }^{b}$ For an upwelling area of $1500 \mathrm{~km}^{2}(10 \times 150 \mathrm{~km})$} \\
\hline 'Mean June flux estimated from Sinclair et al. (1976) & & & \\
\hline
\end{tabular}




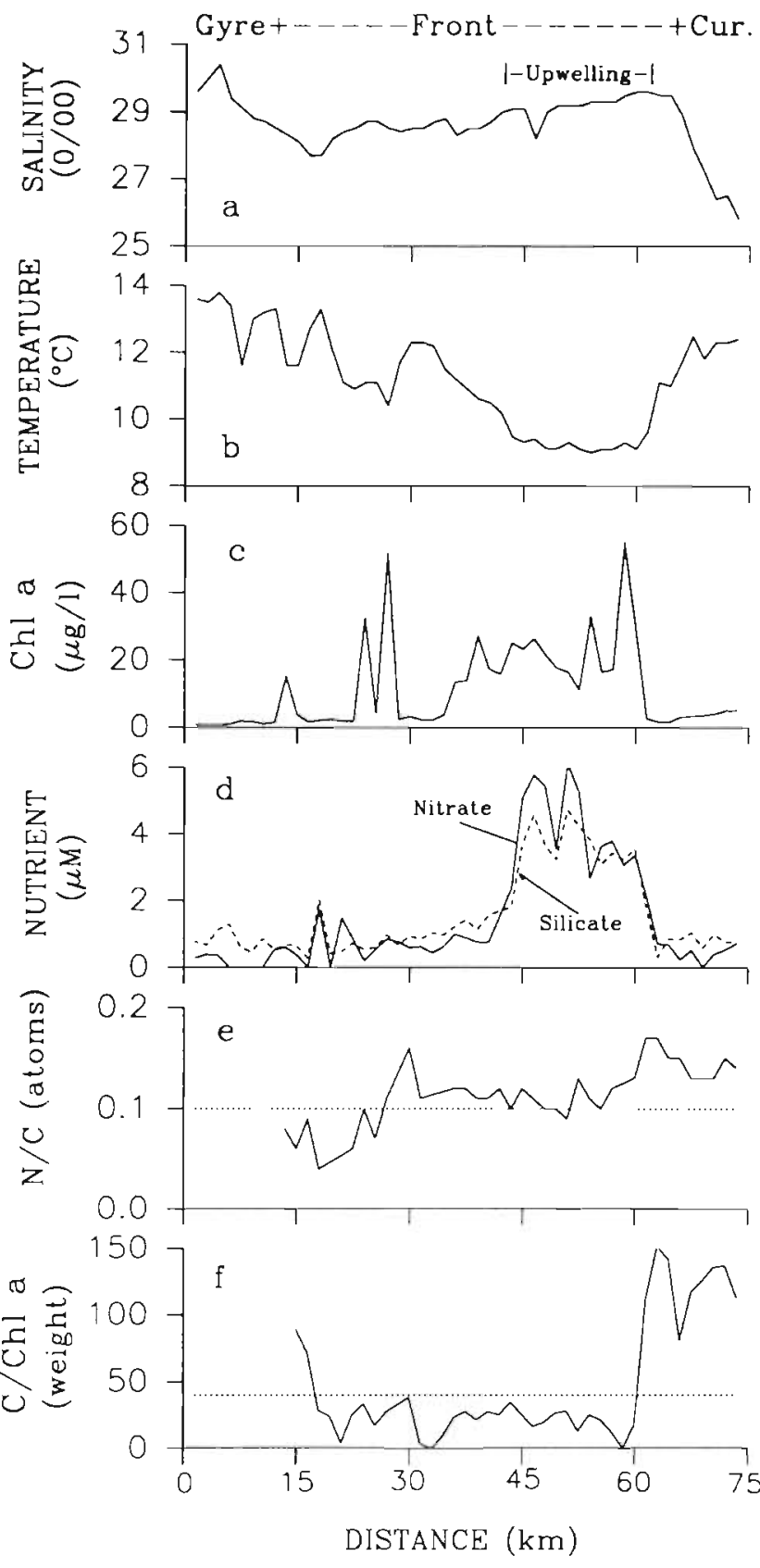

Fig. 9. Horizontal distribution at $3 \mathrm{~m}$ of the variables measured during an upwelling event at the end of June 1985: (a) salinity; (b) temperature; (c) chl a; (d) $\mathrm{NO}_{3}{ }^{-}$and $\mathrm{SiO}_{4}$; (e) N:C ratio of phytoplankton and value of the Redfield ratio (dotted line) (Redfield et al. 1963); and (f) C: chl a ratio and mean value of the ratio for healthy phytoplankton cells (dotted line) (Harrison et al. 1977)

previous studies reported mid-depth nitrate and silicate concentrations similar to those used in our calculations (between 5 and $10 \mu \mathrm{M}$; Coote \& Yeats 1979, Sévigny et al. 1979, Levasseur et al. 1990). Higher nutrient concentrations in the upwelled waters would increase our estimates by a factor of 2 at the most.

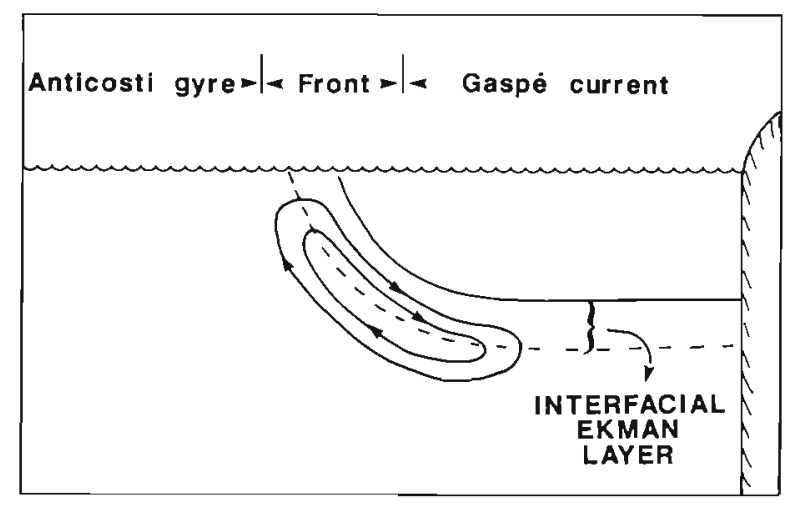

Fig. 10. Schematic representation of the model of cross-frontal circulation proposed by Tang (1980b) for the Gaspe current front. See Fig. 1 for geographical orientation of this model

Under these optimal conditions (i.e. a fully developed upwelling and maximum nutrient concentrations), the contribution of the upwelling to the seaward flux of nutrient would reach $15 \%$ for $\mathrm{NO}_{3}{ }^{-}$and $11 \%$ for $\mathrm{SiO}_{4}$. It is doubtful that this limited contribution could significantly influence secondary and tertiary production in the Gulf.

Variations in surface salinity over the Magdalen Shallows (SW Gulf of St. Lawrence) indicate that the extent of the estuarine plume increases with freshwater runoff (Bugden et al. 1982). Thus, while the upwelling of new nutrients along the front may contribute little to the productivity of the SW Gulf, the seaward extent of the biomass-rich Gaspé current plume during years of high river runoff could directly enhance the growth and survival of invertebrate and fish larvae produced in this area, as suggested by Côté et al. (1985).

Acknowledgements. Thanks to E. Bonneau, S. Cantin, G. Lobb, J. Pauzé, J.-Y. Couture, P. Joli, M. Bolduc, S. Gosselin, S. Toutant, D. Cloutier, M.-J, Martineau, A. Normandeau, R. Pigeon, M. Frénette, S. Levasseur, J. Moisan and T. Van de Velde for their participation in the field collection and the laboratory analysis of the samples. Dr B. R. Heimdal provided taxonomic expertise. Dr Y. de Lafontaine engaged in stimulating discussions and formulated constructive comments. We also thank the captain and crew members of the N.S.C. 'L.M. Lauzier' for their indefatigable support.

\section{LITERATURE CITED}

Benoit, J., El-Sabh, M. I., Tang, C. L. (1985). Structure and seasonal characteristics of the Gaspé Current. J. geophys Res. 90: 3225-3236

Bowman, M. J., Iverson, R. L. (1978). Estuarine and plume fronts. In: Bowman, M. J., Esaias, W. E. (eds.) Oceanic fronts in coastal processes. Springer-Verlag, New York, p. $87-104$

Bugden, G. L., Hargrave, B. T., Sinclair, M. M., Tang, C. L. Therriault, J.-C., Yeats, P. A. (1982). Freshwater runoff 
effects in the marine environment: the Gulf of St. Lawrence example. Can. Tech. Rep. Fish. Aquat. Sci. 1078: $1-89$

Coote, A. R., Yeats, P. A. (1979). Distribution of nutrients in the Gulf of St. Lawrence. J. Fish. Res. Bd Can. 36: 122-131

Côté, B., El-Sabh, M., de la Durantaye, R. (1985). Biological and physical characteristics of a frontal region associated with the arrival of spring freshwater discharge in the southwestern Gulf of St. Lawrence. In: Skreslet, S. (ed.) The role of freshwater outflow in coastal marine ecosystems. Springer-Verlag, New York, p. 261-271

Denman, K. L., Powell, T. M. (1984). Effects of physical processes on planktonic ecosystems in the coastal ocean. Oceanogr. mar. Biol. Ann. Rev. 22: 125-168

Dortch, Q., Clayton, J. R. Jr Thoresen, S. S., Cleveland, J. S., Bressler, S. L., Ahmed, S. I. (1985). Nitrogen storage and use of biochemical indices to assess nitrogen deficiency and growth rate in natural plankton populations. J. mar. Res, 43: 437-464

Drinkwater, K. F., Harding, G. C., Vass, W. P., Gauthier, D. (1991). The relationship of Quebec lobster landings to freshwater runoff and wind storms. In: Therriault, J.-C. (ed.) The Gulf of St. Lawrence: small ocean or big estuary? Can. Spec. Publ. Fish. Aquat. Sci. 113, p. $179-187$

El-Sabh, M. I. (1976). Surface circulation pattern in the Gulf of St. Lawrence. J. Fish. Res. Bd Can. 33: 124-138

El-Sabh, M. I. (1979). The lower St. Lawrence Estuary as a physical oceanographic system. Naturaliste can. 106: $44-74$

El-Sabh, M. I., Benoît, J. (1985). Variabilité spatio-temporelle du courant de Gaspé. Sciences et techniques de l'eau 17 : $55-61$

Falkowski, P. G. (1984). Kinetics of adaptation to irradiance in Dunaliella tertiolecta. Photosynthetica 18: 62-68

Harris, G. P. (1980). Temporal and spatial scales in phytoplankton ecology: mechanisms, methods and management. Can. J. Fish. Aquat. Sci. 37: 877-900

Harrison, P. J., Conway, H. L., Holmes, R. W., Davis, C. O. (1977). Marine diatoms grown in chemostats under silicate or ammonium limitation. III. Cellular chemical composition and morphology of Chaetoceros debilis, Skeletonema costatum and Thalassiosira gravida. Mar. Biol. 43: 19-31

Holligan, P. M. (1981). Biological implications of fronts on the northwest European continental shelf. Phil. Trans. R. Soc. Lond. Ser. A 302: 547-562

Holm-Hansen, O., Lorenzen, C. J., Holmes, R. N., Strickland, J. D. H. (1965). Fluorometric determination of chlorophyll. J. Cons int. Explor. Mer 30: 3-15

James, I. D. (1978). A note on the circulation induced by a shallow-sea front. Estuar coast mar. Sci. 7: 197-202

Kahru, M., Nômmann, S., Simm, M., Vilbaste, K. (1986) Plankton distributions and processes in the Baltic boundary zones. In: Nihoul., J. C. J. (ed.) Marine interfaces ecohydrodynamics. Elsevier, New York, p. 273-294

Krause, G., Budeus, G., Gerdes, D., Schaumann, K, Hesse, K. (1986). Frontal systems in the German Bight and their physical and biological effects. In: Nihoul, J. C. J. (ed.) Marine interfaces ecohydrodynamics. Elsevier, New York, p. $119-140$

Le Fèvre, J. (1986). Aspects of the biology of frontal systems. Adv. mar. Biol. 23: 163-299

Legendre, L., Demers, S., Lefaivre, D. (1986). Biological production at marine ergoclines. In: Nihoul, J. C. J. (ed.) Marine interfaces ecohydrodynamics. Elsevier, New York, p. $1-30$

Levasseur, M., Therriault, J.-C., Legendre, L. (1984). Hierar- chical control of phytoplankton succession by physical factors. Mar. Ecol. Prog. Ser. 19: 211-222

Levasseur, M. E., Harrison, P. J., Heimdal, B. R., Therriault, J. -C. (1990). Simultaneous nitrogen and silicate deficiency of a phytoplankton community in a coastal jet-front. Mar. Biol. 104: 329-338

Loder, J. W., Platt, T (1984). Physical controls on phytoplankton production at tidal fronts. In: Gibbs, P. E. (ed.) 19th EMBS: Plymouth, England. Cambridge University Press, Cambridge, p. 16-21

Lund, J. W. G., Kipling, C., Lecren, E. D. (1958). The inverted microscope method of estimating algal numbers and the statistical basis of estimation by counting. Hydrobiologia 11: $143-178$

Parsons, T. R., Maita, Y., Lalli, C. M. (1984). A manual of chemical and biological methods for seawater analysis. Pergamon Press, Oxford

Redfield, J. L., Ketchum, B. H., Richards, F. A. (1963). The influence of organisms on the composition of sea water. In: Hill, M. N. (ed.) The sea. John Wiley \& Sons, New York, p. $26-77$

Richardson, K., Heath, M. R., Pedersen, S. M. (1986). Phytoplankton distribution and primary productivity in relation to hydrographic features. Dana 6: 25-36

Sakshaug, E., Andreses, K., Myklestad, S., Olsen, Y. (1983). Nutrient status of phytoplankton communities in Norwegian waters (marine, brackish and fresh) as revealed by their chemical composition. J. Plankton Res. 5: 175-196

Sakshaug, E., Olsen, Y. (1986). Nutrient status of phytoplankton blooms in Norwegian waters and algal strategies for nutrient competition. Can. J. Fish. Aquat. Sci. 43: 389-396

Seliger, H. J., McKinley, K. R., Biggley, W. B., Aspden, K. R. H. (1981). Phytoplankton patchiness and frontal regions. Mar. Biol. 61: 119-131.

Sévigny, J.-M., Sinclair, M., El-Sabh, M. I., Poulet, S., Coote, A. (1979). Summer plankton distribution associated with the physical and nutrient properties of the Northwestern Gulf of St. Lawrence. J. Fish. Res. Bd Can. 36: 187-203

Sharp, J. H. (1974). Improved analysis for 'particulate' organic carbon and nitrogen from seawater. Limnol. Oceanogr. 19: 984-988

Sinclair, M., El-Sabh, M. I., Brindle, J.-R. (1976). Seaward nutrient transport in the lower St. Lawrence estuary. J. Fish. Res. Bd Can. 33: 1271-1277

Sinclair, M., Subba Rao, P. V., Couture, R. (1981). Phytoplankton temporal distribution in estuaries. Oceanologica Acta 4: $239-246$

Sutcliffe, W. H. Jr (1972). Some relations of land drainage, nutrients, particulate material, and fish catch in two eastern Canadian bays. J. Fish. Res. Bd Can. 29: 357-362

Sutcliffe, W. H. Jr. (1973). Correlations between seasonal river discharge and local landings of American Lobster (Homarus americanus) and Atlantic Halibut (Hyppoglossus hippoglossus) in the Gulf of St. Lawrence. J. Fish. Res. Bd Can. 30: 856-859

Tang, C. L. (1980a). Observation of wavelike motion of the Gaspé Current. J. phys. Oceanogr 10: 853-860

Tang. C. L. (1980b). Mixing and circulation in the northwestern Gulf of St. Lawrence: a study of a buoyancy driven current system. J. geophys. Res. 25: 2787-2796

Tang, C. L. (1982). A model for frontal upwelling. In: Nihoul, J. C. J. (ed.) Hydrodynamics of semienclosed seas. Elsevier, New York, p. 329-348

Tang, C. L. (1983). Cross-front mixing and frontal upwelling in a controlled quasi-permanent density front in the Gulf of St. Lawrence. J. phys. Oceanogr. 13: 1468-1481 
Therriault, J.-C., Levasseur, M. (1985). Control of phytoplankton production in the lower St. Lawrence estuary: light and freshwater runoff. Naturaliste can. 112: 77-96

Tyler, M. A., Seliger, H. H. (1978). Annual subsurface transport of a red tide dinoflagellate to its bloom area: water circulation patterns and organism distribution in the Chesapeake Bay. Limnol. Oceanogr. 23: 227-246

Tyler, M. A., Seliger, H. H. (1981). Selection for a red tide organism: physiological response to the physical environment. Limnol. Oceanogr. 26: 310-324

This article was submitted to the editor
Van Heijst, G. J. F. (1986). On the dynamics of a tidal mixing front. In: Nihoul, J. C. J. (ed.) Marine interfaces ecohydrodynamics. Elsevier, New York, p. 165-194

Wilkerson, F. P., Dugdale, R. C. (1987). The use of large shipboard barrels and drifters to study the effects of coastal upwelling on phytoplankton dynamics. Limnol. Oceanogr. 32: $368-382$

Yentsch, C. S., Menzel, D. W (1963). A method for the determination of phytoplankton chlorophyll and phaeophytin by fluorescence. Deep Sea Res. 10: 221-231

Manuscript first received: March 4, 1992

Revised version accepted: July 22, 1992 